\title{
1. Introduction to Business Law and Economics for Civil Law Systems
}

Business law is currently one of the most dynamic fields of legal theory and practice. It is the source of a wealth of new structures and institutions, ${ }^{1}$ and is a magnet attracting researchers and graduate students wanting to understand and explain what is happening before our very eyes.

It was not always so. Not long ago, business law had the reputation of being technical, with the implication of being stuffy and devoid of significant policy debate. One could be forgiven for such a view: a look at bankruptcy codes, corporate statutes or securities regulation and the impenetrable style in which many of their provisions are cast provides ample evidence of the technicality of the area. A glance at corporate structures, at lengthy prospectuses or at dense merger agreements only amplifies that view.

Yet, that view is mistaken. The changeover took place during the last decades of the past century. In a seminal article entitled After the Revolution in Corporate Law, Roberta Romano identifies three factors that in her view have signalled the transformation of the study of this area of law from an "ossified, stagnant field" to one of the most intellectually vibrant fields of law altogether. ${ }^{2}$ The first was the development of modern financial theory, which cast a new light on financial markets and securities regulation. A second stems from the new theory of the firm that spurred a wave of path-breaking scholarship in microeconomics and subsequently in corporate law. The third arose from practitioners whose innovation led to new financing techniques that challenged corporate law and securities regulation. All three factors are part and parcel of the law and economics revolution. Although Romano's article focuses on corporate law and securities regulation, the trend she identifies of both theory and practice as the driving forces behind the penetration of economic analysis would seem to apply to all other areas of business law.

At the core of business law lie principles that are essential to our market economy and warrant debate in terms that can be made transparent with the tools law and economics provides. From a policy perspective, a central issue is the place and meaning of value creation and accountability as the goals for

See for instance Pistor 2019.

Romano 2005. 
business law. ${ }^{3}$ This calls for a reflection on the purpose of legal regimes as well as the effectiveness of the solutions put in place to implement them. We need to think through the proper legal approaches for tackling these challenges, such as State-imposed mandatory rules, incentive-based rules and enabling market-based rules. This requires us to understand the behaviour of firms and individuals in their short- or long-term interactions in organisational and transactional settings. Fostering value creation also presupposes the craft of properly drafting contracts and of fashioning institutional mechanisms that provide incentives and safeguards. ${ }^{4}$

To address these issues, a purely positivist approach to law will not do. The codes, legislative texts, international treaties and jurisprudence provide in themselves little insight into the role of legal institutions and their economic effects. We need to draw on the social sciences to critically appreciate the role of the law, both its power and its limits. Social sciences "all seek descriptively, or positively, to understand how humanly created institutions (including laws) affect behaviour, and, normatively, to understand how changes in these institutions would affect behaviour". 5

In the companion volume to this book, Law and Economics for Civil Law Systems, we argue that it is economics, among the social sciences, that has made the most promising advances for law. "In any discussion of 'Law-and-', the elephant in the room is Law and Economics (L\&E). Economic analysis has had greater success than any other discipline as a coloniser of legal scholarship". ${ }^{7}$ As Sanchez-Graells explains,

economic theory can help resolve issues of legal decision-making by providing both a methodology for the analysis of the legal reality to which the decision relates (i.e. contributing to the decision-making process by structuring it and helping us focus on relevant factors), and a normative framework and workable criteria to favour some alternatives over others (i.e. providing a decision-making benchmark). ${ }^{8}$

More particularly, the economic analysis of law can provide three types of service to legal scholars and practitioners. First, it provides tools to determine the main effects of a rule change. Second, it aims to shed light on the rationale for the rules that are observed in existing systems. Third, it provides tools for judging the desirability of a proposed change in law or the choice between opposing legal conclusions in a particular case.

Tirole 2017.

Gilson 1984.

Trachtman 2004, 67.

Mackaay 2021a.

Rose 2010, 369.

Sanchez-Graells 2018, 170. See also Farnsworth 2007. 
Although it is used in all areas of law, economic analysis has gained unparalleled popularity in business law, where it is currently the main paradigm for understanding that field of law in Anglo-American jurisdictions. For instance, the leading textbooks in competition law, corporate law, insolvency law, intellectual property and securities regulation bear the mark of L\&E. ${ }^{9}$ Likewise, economic theory dominates the research agenda in this field.

In civil law jurisdictions, there was initial resistance of legal academia to economics. ${ }^{10}$ Since the turn of the century, this has clearly changed and L\&E is currently enjoying increasing interest in Europe, Latin America and Asia, ${ }^{11}$ with academic programmes in most European Union (EU) countries and an Erasmus doctoral programme tying together the universities of Bologna, Hamburg, Rotterdam and Rennes $1 .{ }^{12}$ Textbooks were published to present the foundations, methodology and applications of economic analysis in the context of civil law systems. ${ }^{13}$ Numerous research monographs and doctoral dissertations have been published over the past decade. A look at the agenda of the annual conference of the Brazilian, European and Latin American and Caribbean Economic Association law and economics associations should convince one of the broad dissemination of the approach in legal scholarship. ${ }^{14}$ Again, it is the field of business law that proves to be a particularly fertile ground for L\&E research.

The goal of this book, as a companion to Law and Economics for Civil Law Systems, is to open a window on the role and contribution of economic analysis of business law from a civilian perspective. Indeed, a distinctive feature of our approach is the integration of comparative law in the discussion. In the field of business law, a comparative approach is a must, given globalisation, economic integration and the dissemination of national models through contracts, choice of law, and practice. ${ }^{15}$ Here we apply economic analysis to the principal areas of business law by looking at the American, Canadian, French and European legal regimes, drawing on the civil law and common law traditions. This

\footnotetext{
9 See the further reading section in each of the relevant chapters.

10 Garoupa 2011.

11 Garoupa 2016, 173: "looking at current trends in Europe, Law and Economics is in much better shape in Italy, Germany, and Spain than in the United Kingdom or in Ireland". Yun-chien Chang, at the Academia Sinica, Taipei, Taiwan, is a leading scholar in East Asia. Active Latin American scholars are too numerous to list. They regularly meet at the Latin American Association (ALACDE - http://www.alacde.org) annual meetings. ALACDE has its own scholarly journal.

12 See https://edle-phd.eu (last accessed 30 July 2021).

13 See, e.g., Deffains 2009; Mackaay 2021b; Sztajn 2005; Schäfer 2020.

14 See also the bibliography to each chapter in this book for references to recent L\&E scholarship in business law from a civil law perspective.

15 Ventoruzzo 2015.
} 
allows us to highlight convergence as well as divergence of approaches across jurisdictions thus enriching our economic inquiry of legal solutions.

The book has six substantive chapters. After this introduction, Chapter 2 presents competition law, probably the oldest branch of law analysed using concepts and theories borrowed from economics. Then follows intellectual property in Chapter 3, where we explain how it borrows features from classical property yet differs from it in its essence. Chapter 4 deals with the essential business vehicles that are corporations, of which we will see the foundations, structures and governance. Chapter 5 deals with the regulation of financial markets that critically support economic activities. Among the means of increasing the confidence necessary to grant financing for commercial activities is secured credit, an institution whose principles were already known in Roman law and which we deal with in Chapter 6. The last chapter provides an analysis of the rules to apply when business turns out to be less profitable than expected and the individual or company can no longer meet its commitments. To avoid a chaotic rush on its assets and organise an orderly dismantling, modern legal systems recognise insolvency and restructurings (Chapter 7). A conclusion wraps up what we have learnt.

\section{BIBLIOGRAPHY}

Deffains 2009: Deffains, Bruno and Éric Langlais, Analyse économique du droit, Bruxelles, De Boeck, 2009

Farnsworth 2007: Farnsworth, Ward, The Legal Analyst: A Toolkit for Thinking about the Law, Chicago, University of Chicago Press, 2007

Garoupa 2011: Garoupa, Nuno, "The Law and Economics of Legal Parochialism" (2011) University of Illinois Law Review 1517-29

Garoupa 2016: Garoupa, Nuno, "Updating the Law and Economics of Legal Parochialism", in Alain Marciano and Giovanni Battista Ramello (eds), Law and Economics in Europe and the U.S., New York, Springer, 2016, 171-83

Gilson 1984: Gilson, Ronald J., "Value Creation by Business Lawyers: Legal Skills and Asset Pricing" (1984) 94 Yale Law Journal 239-313

Mackaay 2021a: Mackaay, Ejan, Law and Economics for Civil Law Systems, 2nd ed., Cheltenham, UK and Northampton, MA, USA, Edward Elgar Publishing, 2021.

Mackaay 2021b: Mackaay, Ejan, Stéphane Rousseau, Pierre Larouche and Alain Parent, Analyse économique du droit, 3rd ed., Paris/Montréal, Dalloz/Éditions Thémis, 2021

Pistor 2019: Pistor, Katharina, The Code of Capital: How the Law Creates Wealth and Inequality, Princeton, Princeton University Press, 2019

Romano 2005: Romano, Roberta, "After the Revolution in Corporate Law" (2005) 55 Journal of Legal Education 342-59

Rose 2010: Rose, Carol M., "Game Stories" (2010) 22 Yale Journal of Law and the Humanities 369-91

Sanchez-Graells 2018: Sanchez-Graells, Albert, "Economic Analysis of Law, or Economically Informed Legal Research", in Dawn Watkins and Mandy Burton (eds), Research Methods in Law, 2nd ed., London, Routledge, 2018, 170-93 
Schäfer 2020: Schäfer, Hans-Bernd and Claus Ott, Lehrbuch der ökonomischen Analyse des Zivilrechts, 6th ed., Berlin, Springer-Gabler, 2020

Sztajn 2005: Sztajn, Rachel and Decio Zylbersztajn, Direito \& economia: análise econômica do direito e das organizações, Rio de Janeiro, Elsevier, 2005

Tirole 2017: Tirole, Jean, Economics for the Common Good, Princeton, Princeton University Press, 2017

Trachtman 2004: Trachtman, Joel P., "The Methodology of Law and Economics in International Law" (2004) 6 International Law Forum du droit international 67-72

Ventoruzzo 2015: Ventoruzzo, Marco, Pierre-Henri Conac, Gen Goto, Sebastian Mock, Mario Notari and Arad Reisberg, Comparative Corporate Law, Minneapolis, West Academic Publishing, 2015 